\title{
TAVALLISTA SUJUMATTOMUUTTA: AIKUISTEN PUHEEN SUJUVUUDEN KVANTITATIIVINEN ANALYYSI
}

\author{
Nelly Penttilä, Yhteiskuntatieteiden tiedekunta, Tampereen \\ yliopisto \\ Anna-Maija Korpijaakko-Huuhka, Yhteiskuntatieteiden \\ tiedekunta, Tampereen yliopisto \\ Raymond D. Kent, Waisman Center, University of \\ Wisconsin-Madison
}

Tutkimus käsittelee suomenkielisten aikuisten puheen tyypillisiä sujumattomuuksia ja niiden normaalivariaatiota. Henkilöt $(N=70)$ olivat neurologisesti terveitä, eikä heillä ollut diagnosoituja puheen tai kielen häiriöitä. Heidän sarjakuvakerrontaan perustuvien audioaineistojen transkriptioista analysoitiin puhenopeuden ja artikulaationopeuden lisäksi 10 puheen sujuvuutta kuvaavaa muuttujaa. Tutkimuksessa tarkasteltiin muuttujien yleisyyttä, niiden keskinäisiä suhteita sekä sujumattomuuksien vaikutusta sujumattomuusprosenttiin. Sujumattomuusprosentin keskiarvo oli koko aineistossa 2,3\% (vv = 0,0-7,8\%), ja sitä selittivät vahvimmin muuttujat korjaus ja sanan toisto sekä epäröinti, joka oli myös yleisin sujumattomuustyyppi. Sujumattomuusprosentin mukaan jaetuissa puhujaryhmissä sujumattomuuden tyyppi muuttui sujumattomuusprosentin kasvaessa. Sujumattomuuksista muodostui neljä faktoria: sujumattomuudet, jotka liittyivät 1) kielelliseen muotoiluun, 2) viestin suunnitteluun, 3) viestin jatkuvuuden ylläpitoon ja 4) artikulaatioon. Sujumattomuusprosenttia selittivät parhaiten sujumattomuudet, jotka liittyivät kielelliseen muotoiluun sekä ilmaisun jatkuvuuden ylläpitoon. Tulokset vahvistivat ajatusta puheen sujuvuudesta jatkumona sekä toivat esiin sujumattomuuksien laajan variaation niin määrällisesti kuin laadullisestikin. Tämän aineiston normaalivariaatiota voidaan käyttää sekä häiriödiagnostiikan että kuntoutustavoitteiden asettamisen tukena. Lisäksi tutkimuksen tulokset toimivat vertailupohjana tuleville tutkimuksille.

Avainsanat: aikuiset, normaalivariaatio, puheen sujuvuus, sujumattomuudet, tyypillinen puhe

Kirjoittajien yhteystiedot:

Nelly Penttilä

nelly.penttila@uta.fi

Anna-Maija Korpijaakko-Huuhka

anna-maija.korpijaakko-huuhka@uta.fi

Raymond D. Kent

kent@waisman.wisc.edu

\section{JOHDANTO}

Sujuva puhe on moniulotteinen käsite ja monitieteinen tutkimuskohde, jota voidaan tarkastella niin puhujan kuin kuulijankin näkökulmasta (Kormos \& Dénes, 2004). Segalowitz (2010, s. 48) jakaa sujuvuuden taitotasot kognitiiviseen sujuvuuteen, ilmaisun sujuvuuteen ja kuultuun sujuvuuteen. 
Kognitiivinen sujuvuus tarkoittaa käsitteistön ja lauseenmuodostuksen hallintaa, ilmaisun sujuvuus viittaa ääntämisen ja prosodian luonnollisuuteen ja kuultu sujuvuus kuulijan käsitykseen puhujan sujuvuudesta. Myös logopediassa sujuvuutta voidaan tarkastella monesta suunnasta, sillä kokonaiskäsitys asiakkaan kommunikaatiohäiriöstä syntyy vain yhdistämällä toisiinsa kuulonvaraiset havainnot, asiakkaan puhenäytteistä mitatut tiedot ja hänen kokemuksensa häiriön aiheuttamasta haitasta (McCauley, 1989). Yhteistä sujuvuutta tutkiville tieteenaloille on käsitys puheen sujuvuudesta kehittyvänä ominaisuutena. Tällöin sujuva puhe voidaan nähdä niin puheterapian, oppimisen kuin opettamisenkin tavoitteena.

\section{Sujuvuus psyko-fyysis-sosiaalisena ilmiönä}

Puheemme on sujumattominta ensin lapsuudessa puheen ja kielen kehityksen ollessa nopeassa vaiheessa (Ambrose \& Yairi, 1999; Guitar, 2006, s. 140-145) ja myöhemmin ikääntyessämme puheen motorisen ohjelmoinnin ja kielellisen prosessoinnin hidastuessa (Bortfeld, Leon, Bloom, Schober \& Brennan, 2001; Searl, Gabel \& Fulks, 2002). Myös neurologiset sairaudet kuten aivoverenkiertohäiriöt ja aivovammat voivat lisätä sujumattomuutta (Van Borsel, 2014; Van Lieshout, Bose, Square \& Steele, 2007). Sekä häiriintyneessä että ns. tyypillisessä puheessa esiintyy kuitenkin samankaltaisia sujumattomuuksia, esimerkiksi epäröintiä, vääriä sanavalintoja ja tavujen toistoja. Jotta kliinisessä puheterapiatyössä voidaan erottaa sujuvuuden häiriö tyypillisestä sujumattomuudesta, tarvitsemme tietoa tyypillisen sujumattomuuden piirteistä ja yleisyydestä.

Sujuvaa puhetta voidaan tarkastella yksittäisen puheentuottoa kuvaavan prosessin sijaan fyysisten, psyykkisten ja sosiaalisten prosessien yhteistuloksena. Fyysisiä muuttujia ovat muun muassa anatomiset rakenteet ja niiden toiminta, kuten artikulaatio ja fonaatio (Brown, Ingham, Ingham, Laird \& Fox, 2005; Kent, 2000). Esimerkiksi hidas motorinen prosessointi vaikuttaa puhenopeuteen ja koartikulaatioon, jolloin puhe voi kuulostaa sujumattomalta. Myös ääntöhengityksen katkonaisuus lisää sujumattomuutta muuttamalla puheen rytmiä. Psyykkisistä tekijöistä kielelliset prosessit, kuten sanahaku ja kompleksisen viestin muotoilu, vaikuttavat puheen sujuvuuteen (Lickley, 2001; Oviatt, 1995). Myös puhujan emootiot tai vireystila heijastuvat puheentuottoprosessiin, joko lisäten tai vähentäen sujumattomuuksien määrä (Walden, Frankel, Buhr, Johnson, Conture \& Karrass, 2012). Sosiaalisia muuttujia puolestaan ovat esimerkiksi keskustelutilanne, keskustelukumppanin tuttuus sekä puheenaihe (Bell, Eklund \& Gustafsson, 2000; Bortfeld ym., 2001; Roberts, Meltzer \& Wilding, 2009). Tutun keskustelukumppanin kanssa puheemme on sujuvinta, ja kun puheenaihe ei herätä voimakkaita tunteita tai sisällä kielellisesti haastavaa ainesta, puhe on sujuvampaa kuin tilanteissa, joiden puheenaiheet ovat puhujalle vieraita.

\section{Sujumattomuus viestinnän voimavarana}

Puheen sujumattomuuksia tarkastellaan logopedisessa kirjallisuudessa yleensä virheinä tai häiriöinä, mutta niillä voi olla myös viestintää edistävä tehtävä. Sujumattomuudet ovat usein tahdosta riippumattomia puheen katkoksia, mutta ne voidaan nähdä myös tahdonalaisina kielellisinä ja pragmaattisina valintoina, joita puhuja käyttää sujuvan puheen maksimoimiseksi (Moniz, Batista, Mata \& Trancoso, 2014; O 'Connel \& Kowal, 2005). Yleensä tällaisilla ikään kuin tahdonalaisesti tuotetuilla sujumattomuuksilla pyritään suunnittelemaan ja muotoilemaan 
puhunnosta (Clark \& Wasow, 1998; Clark \& Fox Tree, 2002). Lisäksi sujumattomuuksien avulla puhuja tuo kuulijalle uutta tietoa, esimerkiksi korjaamalla tuotostaan tai vaihtamalla sanaa (Arnold, Fagnano \& Tanenhaus, 2003). Sujumattomuuksilla on siis kommunikatiivinen funktio, sillä esimerkiksi epäröinti toimii kuulijalle vihjeenä tulevan puhunnoksen kompleksisuudesta (Allwood, Nivre \& Ahlsén, 1990; Watanabe, Hirose, Den \& Minematsu, 2008).

Sujumattomuuden laatu vaikuttaa siihen, kuinka hyvin kuulija tunnistaa sanoja ja ymmärtää puhetta (Fox Tree, 1995). Heidän tutkimuksessaan (1995) keskeytykset ja korjaukset hidastivat tunnistamista, mutta sanojen tai fraasien toistot nopeuttivat sitä. Myös Brennan ja Schrober (2001) tekivät vastaavan havainnon. He tarkastelivat sujumattomuuksien, erityisesti epäröinnin, vaikutuksia kuulijaan. Tutkittavina oli 50 opiskelijaa, joille annettiin ohjeita, jotka vaihtelivat sujumattomista täysin sujuviin. Sujumattomissa ohjeissa esiintyi yleensä keskeytys, epäröinti ja korjaus (liikuta pu..öö keltaista neliötä). Puolisujuvissa ohjeissa epäröintiäänne oli korvattu hiljaisella tauolla (liikuta pu....keltaista neliötä,) ja sujuvissa ohjeissa sujumattomuudet oli korvattu kokonaan hiljaisella tauolla (liikuta... keltaista neliötä). Tutkijat havaitsivat, että kuulijat suoriutuivat tehtävästä nopeimmin, kun puheessa esiintyi keskeytyksen jälkeen epäröintiääni (sujumaton ohje). Kuulijat pystyivät hyödyntämään paremmin myös keskeytyksen sisältävää informaatiota ilman epäröintiä (puolisujuva ohje) verrattuna täysin sujuviin ohjeisiin, joissa sujumattomuudet oli korvattu pitkällä hiljaisella tauolla. Brennanin ja Schoberin johtopäätös oli, että epäröintiääni on kuulijalle merkityksellinen, sillä se kompensoi puheessa ilmenevää virhettä eikä siis ole virhe itsessään. Myös puolisujuvissa ohjeissa ollut keskeytys kertoi kuulijalle, että puhujalla on vaikeuksia ja että oikea ohje tulee seuraavaksi. Sujumattomuus siis paljasti virheen, ja mahdollinen korjausjakso tai epäröinti antoi kuulijalle vihjeen siitä, että tulossa oleva ilmaus on informaatioltaan merkittävä, jolloin hänellä oli aikaa reagoida siihen.

\section{Pubeen sujumattomuuden tutkimuslinjoja}

Kansainvälisissä tutkimuksissa aikuispuhujien tuottamia sujumattomuuksia on tarkasteltu joko kognitiivisessa (Bard, Lickley \& Aylett, 2001; Horton \& Gerrig, 2005) tai strategisessa (Clark \& Wasow, 1998; Fox Tree \& Clark, 1997) viitekehyksessä. Kognitiivisessa tarkastelussa sujumattomuuksien ajatellaan olevan seurausta ensisijaisesti kielellisistä hankaluuksista, kun taas strategiseen näkökulmaan perustuvassa tarkastelussa sujumattomuudet nähdään pääosin tahdonalaisesti tuotettuina eli viesteinä kuulijalle. Molemmissa tarkastelutavoissa sujumattomuuksia voidaan analysoida formaalisti eli havainnoiden yksittäisiä sujumattomuuden piirteitä (Johnson 1961; Ambrose \& Yairi, 1999) tai funktionaalisesti, jolloin kohteena ovat sujumattomuuksien "tarkoitukset" (Levelt, 1983; Postma \& Kolk, 1993).

Erityisesti logopedian alan tutkimuksissa formaalinen tarkastelu toteutuu yleisimmin änkytystutkimukseen liittyvänä taksonomisena jaotteluna, jossa "tyypilliset sujumattomuudet" (engl. typical/other disfluencies; sanan toisto, fraasin toisto, keskeytys, korjaus, interjektio ja/tai epäröinti) erotellaan "epätyypillisistä" eli "änkytyksenkaltaisista” sujumattomuuksista (engl. stuttering-like disfluencies; äänteen tai tavun toisto, venytys ja blokki) (Ambrose \& Yairi, 1999; Clark, Conture, Walden \& Lambert, 2015; Gregory, 1993; Johnson, 1961). Formaalissa tarkastelussa tyypillistä sujumattomuutta kuvataan usein sujumattomuusprosentilla (engl. disfluency frequency). Suhdeluku saadaan ja- 
kamalla tyypillisten ja änkytyksenkaltaisten sujumattomuuksien summa näytteen tavu- tai sanamäärällä ja kertomalla tulos sadalla (Logan, 2015, s. 106-107; Yaruss, 1997). Tämän lisäksi änkytyksenkaltaisia sujumattomuuksia tarkastellaan usein erikseen. Siinäkin käytetään suhdelukua, joka saadaan laskemalla änkytyksenkaltaisten sujumattomuuksien määrä sataa tavua tai sanaa kohden (Roberts ym., 2009).

Englanninkielisten terveiden aikuisten spontaanipuheessa sujumattomuuksia esiintyy noin $6 \%$ :ssa sanoista (Bortfeld ym., 2001; Fox Tree, 1995). Jos myös hiljaiset tauot lasketaan sujumattomuuksiksi, sujumattomuuksien osuuden vaihteluväli sataa sanaa kohden on laaja eli 2-26\% (Kasl \& Mahl, 1987; Lutz \& Mallard, 1986). Sujumattomuusprosentin on havaittu kasvavan ilmausten pidentyessä (Oviatt, 1995), tai kun ilmaisu on kieliopillisesti kompleksinen (Lickley, 2001). Myös puhetilanne vaikuttaa sujumattomuusprosenttiin siten, että puhelinkeskusteluissa olemme sujumattomampia kuin kasvokkaisissa vuorovaikutustilanteissa (Bell ym., 2000). Sujumattomuusprosentin on havaittu vaihtelevan myös puheenaiheen mukaan. Robertsin työryhmän (2009) tutkimuksessa tarkasteltiin 25 englantia puhuvan aikuisen puheen sujuvuutta (iän keskiarvo $=31,8 \mathrm{v}$, vaihteluväli $=20-$ $51 \mathrm{v})$ kolmesta spontaanipuheen näytteestä, joiden aiheet vaihtelivat (kerro työstäsi, kerro harrastuksistasi, kerro miten tennistä/jääkiekkoa pelataan). Näytteistä analysoitiin interjektiot (uh, um, like, you know), korjaukset, fraasien toistot, sanojen toistot, äänteiden ja tavujen toistot, venytykset sekä blokit. Eniten sujumattomuuksia ilmeni puhujien kertoessa harrastuksestaan $(\mathrm{ka}=7,56 \%$, vaihteluväli $=2,3-12,2 \%)$ ja vähiten heidän puhuessaan työstään $(\mathrm{ka}=6,87 \%$, vaihteluväli $=2,3-13,0$ $\%)$. Yleisin sujumattomuustyyppi oli interjektio, mikä on havaittu myös muissa aikuispuhujien aineistoissa - terminologiasta riippuen samaa on tarkoitettu käsitteillä täytetty tauko (McDougall \& Duckworth, 2017), filleri (Bortfeld ym., 2001) tai epäröinti (Duchin \& Mysak, 1987).

Funktionaalisen lähestymistavan mukaan sujumattomuuksia tarkastellaan puhujalle merkityksellisinä vuorovaikutuksen osatekijöinä (Levelt, 1983, Postma \& Kolk, 1993). Logopediassa funktionaalinen lähestymistapa on liittynyt vahvasti tutkimuksiin, joissa on tarkasteltu apraksian (Liss, 1998) ja afasian (Laakso, 1997; Milroy \& Perkins, 1992; Oomen, Postma \& Kolk, 2001) vaikutusta puheeseen. Erityisesti itsekorjaukset ovat kiinnostaneet tämän viitekehyksen valinneita tutkijoita. Myös Levelt (1983) on tutkinut sujumattomuuksien rakennetta ja itsekorjausten merkityksiä. Hän jakaa sujumattomuuden rakenteen kuuteen eri osaan (kuvio 1). Kuvion 1 esimerkkilauseen alussa ilmenee korjausta vaativa / $\mathrm{mi} /$-tavu (reparandum), jota seuraa rajapinta sujumattoman ja sujuvan puheen välillä (interruption point). Esimerkkilauseessa on tämän jälkeen tauko (interregnum) ja sen jälkeen korjauspartikkeli / eiku/, joka ilmaisee tuotetun virheen ja aloitetun korjauksen (editing). Lopuksi esimerkissä on korjaus, /sinä/, eli sujuva puhetuotos (repair), josta alkaa taas sujuva puhejakso sanalla /söit/ (continuation).

Kuvio 1. Leveltin (1983) itsekorjauksen malli
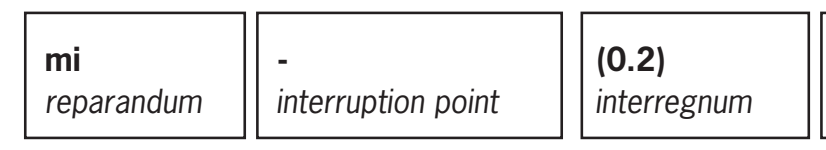

eiku
editing

sinä
repair




\section{Tutkimuksen tarkoitus}

Puheen tyypillistä sujuvuutta tarkasteleva kotimainen tutkimus on painottunut kielitieteen ja soveltavan kielitieteen tutkimusalueille, joiden näkökulma on usein vierasta kieltä oppivien puhujien kielellisessä sujuvuudessa tai sitten suomenkielisten puhujien taukojen sekä puhe- ja artikulaationopeuksien tarkastelussa (mm. Lehtonen, 1978; Moore, 1991; Moore \& Korpijaakko-Huuhka, 1996; Sallinen-Kuparinen, 1990; Ullakonoja, 2008). Ymmärryksemme suomenkielisten aikuisten tyypillisestä sujuvuudesta ja sujumattomuudesta perustuu siis pääosin puhe- ja artikulaationopeuksien tarkasteluun, eikä sujumattomuuksien määrälisiä tai laadullisia analyyseja ole tehty. Puheen sujumattomuudet lisääntyvät neurologisten vammojen ja sairauksien, kuten Parkinsonin taudin, aivoverenkiertohäiriön tai muistisairauksien myötä (Goberman, Blomgren \& Metzger, 2010; Lee, Gayraud, Hirsh \& Barkat-Defradas, 2011; Lundgren, Helm-Estabrooks \& Klein, 2010). Siksi tarvitsemme tietoa tyypillisestä sujumattomuudesta kliinisen työn tueksi niin arviointiin, kuin kuntoutuksen tavoitteiden asettamiseenkin, sekä tulevien tutkimusten vertailuaineistoksi. Näiden tavoitteiden saavuttamiseksi tässä tutkimuksessa kuvataan suomenkielisten terveiden aikuisten puheen sujumattomuuksien laatua ja määrää seuraavien tutkimuskysymysten kautta:
Millainen on puheen sujuvuuden variaatio suomenkielisillä aikuisilla?

Millaiset tekijät selittävät parhaiten sujumattomuusprosenttia?

Millaisia keskinäisiä suhteita sujumattomuustyypeillä on?

\section{AINEISTO JA MENETELMÄT}

\section{Tutkittavat}

Tutkimushenkilöiksi haettiin terveitä suomenkielisiä puhujia taulukossa 1 esitettyjen kriteerien mukaisesti. Tutkimuksesta tiedotettiin eri kaupunkien (Tampere, Helsinki, Joensuu, Kouvola) julkisissa tiloissa ja niin sanotun puskaradion kautta. Vapaaehtoisia tutkimushenkilöitä ilmoittautui 76, jotka kaikki haastateltiin ${ }^{1}$. Puheterapeutin (1. kirjoittaja) tekemän haastattelun perusteella kuusi tutkittavaa jätettiin tutkimuksen ulkopuolelle joko artikulaatiovirheen, hoidetun kehityksellisen änkytyksen, vahvan vieraskielisen kieliympäristön tai änihäiriön vuoksi. Tutkimusryhmään tuli siten 70 suomalaispuhujaa. Heistä 36 oli naisia ja 34 miehiä (iän vaihteluväli $=$ $18-89 \mathrm{v}, \mathrm{kh}=14 \mathrm{v})$. Tutkittavien tiedot on koottu taulukkoon 2.

1 Ensimmäisen kirjoittajan lisäksi aineistonkeruuseen osallistui kymmenen tutkittavan osalta filosofian maisteri Iina Kaasalainen (nyk. Vaarala).

Taulukko 1. Tutkittavien valintakriteerit

\begin{tabular}{|l|l|}
\hline Inkluusiokriteerit & Ekskluusiokriteerit \\
\hline Suomi äidinkielenä & kaksikielisyys \\
Täysi-ikäisyys & kehityksellinen kommunikoinnin häiriö \\
& $\begin{array}{l}\text { hankittu kommunikoinnin häiriö } \\
\text { muistisairaus } \\
\text { kuulovamma }\end{array}$ \\
\hline
\end{tabular}


Taulukko 2. Tutkittavien taustatiedot ikäryhmittäin

\begin{tabular}{|c|c|c|c|c|}
\hline Ikäryhmä & $\mathrm{N}$ & Osuus & Kätisyys (O/V) & Koulutus \\
\hline $18-28$ & 8 & $11,4 \%$ & $0100 \%$ & $\begin{array}{l}\text { Toisen asteen koulutus } 62,5 \% \\
\text { Korkeakoulututkinto } 12,5 \% \\
\text { Ylempi korkeakoulututkinto } 25 \%\end{array}$ \\
\hline $29-49$ & 47 & $67,1 \%$ & O $85,1 \% / V 14,9 \%$ & $\begin{array}{l}\text { Peruskoulu 2,1\% } \\
\text { Toisen asteen koulutus 25,6\% } \\
\text { Korkeakoulututkinto 38,3\% } \\
\text { Ylempi korkeakoulututkinto } 34 \%\end{array}$ \\
\hline $50-65$ & 9 & $12,9 \%$ & O $88,8 \% / V 11,1 \%$ & $\begin{array}{l}\text { Toisen asteen koulutus } 44,4 \% \\
\text { Korkeakoulututkinto } 44,4 \% \\
\text { Ylempi korkeakoulututkinto } 11,2 \%\end{array}$ \\
\hline $66-89$ & 6 & $8,6 \%$ & O 83,3 \%/V 16,7\% & $\begin{array}{l}\text { Peruskoulu 16,7\% } \\
\text { Toisen asteen koulutus 33,3\% } \\
\text { Korkeakoulututkinto } 50 \%\end{array}$ \\
\hline
\end{tabular}

\section{Aineiston analyysi}

Tutkittavilta kerättiin puhenäytteet spontaanipuheesta, semispontaanista puheesta ja toistopuheesta. Kaikki puhenäytteet tallennettiin Zoom $\mathrm{H} 2$-äänitallentimella puhujan valitsemassa paikassa. Tämän tutkimuksen aineistoksi valittiin semispontaanit puhenäytteet, joissa tutkittavat kertovat 9-ruutuiseen sarjakuvaan perustuen ns. variksenpelätinkertomuksen (Henning Dahl Mikkelsenin Fugleskräemsel går amok; ks. KorpijaakkoHuuhka, 2003). Semispontaani puhenäyte mahdollisti näytteiden keskinäisen vertailun, kun topiikki oli kaikille sama. Näitä semispontaaneja puhenäytteitä on käytetty myös Penttilän, Korpijaakko-Huuhkan ja Kentin (2018a) tutkimuksessa, jossa sujuvuutta arvioitiin kuulonvaraisesti.

Aineisto rajattiin sisällöllisesti siten, että analyysiin otettiin mukaan tutkittavien kuvista 2-7 tuottama puhe. Päätös rajata puhenäytteet sisällön perusteella perustui sekä työmäärän kohtuullistamiseen, että Penttilän ym. (2018a) tutkimukseen, jossa puheen sujuvuutta arvioitiin näistä semanttisesti rajatuista ääniaineistoista kuulonvaraisesti. Puhenäytteiden tavujen määrän keskiarvo oli 170 (vaihteluväli $=97-401, \mathrm{Md}=158$, $\mathrm{kh}=52,3)$.

Puhenäytteistä muodostettiin transkriptiot Praat-ohjelmalla (Boersma \& Weenink, 2010). Aineistosta analysoitiin puhenopeuden (tavuja/sekunnissa) ja artikulaationopeuden (tavuja/sekunnissa ilman taukoja) sekä hiljaisten taukojen kestojen (tarkkuus 0,1 s) lisäksi 10 erilaista puheen sujuvuuden muuttujaa. Sujumattomuuksia tarkasteltiin formaalisti eli perinteiseen änkytystutkimukseen perustuvan taksonomian kautta (Ambrose \& Yairi, 1999), jossa sujumattomuudet jaettiin joko tyypillisiin (engl. other disfluencies; taulukko 3) tai änkytyksenkaltaisiin (engl.stuttering-like disfluencies; taulukko 4). Jos sanassa esiintyi useampi sujumattomuus, laskettiin kukin sujumattomuus erikseen.

Mitatuista muuttujista muodostettiin sujumattomuusprosentti laskemalla sujumattomuuksien määrän prosentuaalinen osuus sataa tavua kohden (sujumattomuuk- 
sien määrä / näytteen tavumäärä x 100). Änkytyksenkaltaisista sujumattomuuksista muodostettiin lisäksi oma suhdeluku (taulukko 4) jakamalla änkytystenkaltaisten sujumattomuuksien määrä näytteen tavumäärällä ja kertomalla sadalla. Luokitusten luotettavuus arvioitiin Inter-Rater Reliability -tutkimuksella, jossa kahden luokittelijan yksimielisyys todettiin korkeaksi (IRR = 81,6\%).

Aineisto käsiteltiin tilastollisesti SPSS 24.0-ohjelmalla (2016). Sujumattomuuksien keski- ja hajontalukujen kuvaamisen jälkeen, puhujien sujumattomuusprosentteja tarkasteltiin klusterianalyysin avulla normaalivariaation hierarkkisuuden selvittämiseksi. Tämän jälkeen yksittäisten sujumattomuustyyppien vaikutusta sujumattomuusprosenttiin tarkasteltiin regressioanalyysilla. Muuttujien keskinäisiä suhteita tulkittiin faktorianalyysin avulla. Lisäksi sukupuolen ja kätisyyden vaikutusta sujumattomuusprosenttiin tarkasteltiin Mann-Whitney U -testillä ja iän, koulutustason sekä tavumäärän vaikutusta Kruskal-Wallisin testillä.

Taulukko 3. Tyypillisen sujuvuuden muuttujat (esimerkit tästä aineistosta)

\begin{tabular}{|c|c|c|}
\hline Muuttuja & operationaalinen määritelmä & selitykset ja esimerkit \\
\hline Interjektio & $\begin{array}{l}\text { interjektioiden kokonaismäärä } \\
\text { näytteestä }\end{array}$ & $\begin{array}{l}\text { viestin kannalta merkityksettömät } \\
\text { täytesanat, huudahdukset, ja } \\
\text { puhunnoksen aloittavat "startterit" } \\
\text { [noni], [no], [okei], [jaaha], [ai] }\end{array}$ \\
\hline Epäröinti & $\begin{array}{l}\text { epäröintien (ns. täytettyjen } \\
\text { taukojen) kokonaismäärä } \\
\text { näytteestä }\end{array}$ & $\begin{array}{l}\text { vokaali tai vokaalinasaaliääntö, jolla } \\
\text { puhuja täyttää hiljaisen tauon } \\
{[\text { öö], }[\mathrm{mm}],[\mathrm{aa}],[\mathrm{hmm}]}\end{array}$ \\
\hline $\begin{array}{l}\text { Sanan } \\
\text { toisto }\end{array}$ & $\begin{array}{l}\text { toistettujen sanojen } \\
\text { kokonaismäärä näytteestä }\end{array}$ & $\begin{array}{l}\text { [sitä }(0.5) \text { sitä tota viljelytouhua] } \\
\text { [siellä sen }(1.2) \text { sen }(1.2) \text { variksen] } \\
\text { [hän kaivaa }(0.5) \text { kaivaa }(0.9) \\
\text { kuoppia }(1.5) \text { ja }(0.5) \text { kuoppia } \\
\text { kasvimaalla] }\end{array}$ \\
\hline $\begin{array}{l}\text { Fraasin } \\
\text { toistot }\end{array}$ & $\begin{array}{l}\text { toistettujen fraasien } \\
\text { kokonaismäärä näytteestä }\end{array}$ & [se ottaa (0.2) se ottaa] \\
\hline Keskeytys & $\begin{array}{l}\text { keskeytettyjen äänteiden/tavujen/ } \\
\text { sanojen/fraasien kokonaismäärä } \\
\text { näytteestä }\end{array}$ & $\begin{array}{l}\text { [oli var }(.) \text { valmis] } \\
{[\text { mies aik }(0.2) \text { hän hakee tuolta] }} \\
\text { [öö pelotte pelottimen] }\end{array}$ \\
\hline Korjaus & $\begin{array}{l}\text { korjausten kokonaismäärä } \\
\text { näytteestä }\end{array}$ & $\begin{array}{l}\text { Virheelliset tai onnistuneet } \\
\text { korjaukset/uudelleenmuotoilut } \\
\text { [variksenpelätin oli var }(0.3) \text { valmis] } \\
\text { [öö pelotte pelottimen] }\end{array}$ \\
\hline
\end{tabular}


Taulukko 4. Epätyypillisen sujuvuuden muuttujat eli änkytyksenkaltaiset sujumattomuudet (stuttering like disfluencies $=$ SLD)

\begin{tabular}{|c|c|c|}
\hline Muuttuja & operationaalinen määritelmä & Mahdollinen esimerkki \\
\hline toisto & $\begin{array}{l}\text { toistettujen äänteiden tai } \\
\text { tavujen kokonaismäärä }\end{array}$ & $\begin{array}{l}\text { [niku }(0.1) \text { ha-haaveilee noista] } \\
\text { [ba-banaaneita ehkä] }\end{array}$ \\
\hline venytys & kokonaismäärä & [va::riksen]* \\
\hline $\begin{array}{l}\text { katkos fonaatiossa } \\
\text { eli blokki }\end{array}$ & $\begin{array}{l}\text { kokonaismäärä ja blokin } \\
\text { ajallinen kesto }\end{array}$ & [sillä $\mathbf{k}^{\prime}(\mathbf{0} .4)$ aivetaan]* \\
\hline SLD-prosentti & $\begin{array}{l}\text { Änkytyksenkaltaisten } \\
\text { sujumattomuuksien } \\
\text { määrän suhteellinen osuus } \\
\text { kokonaistavumäärästä. }\end{array}$ & $\begin{array}{l}\text { Näyte: ha-haaveilee noista } \\
\text { Analyysi: } 1 \text { änkytys, } 5 \text { sujuvaa tavua } \\
\text { Kaava: }(1: 5) \times 100=20 \% \\
\text { Änkytyksenkaltaisiksi } \\
\text { sujumattomuuksiksi määriteltiin } \\
\text { äänteen- tai tavun ponnisteiset ja } \\
\text { nopeat toistot, äänteiden venytykset } \\
\text { ja katkokset (ns. blokit). }\end{array}$ \\
\hline $\begin{array}{l}\text { Änkytyksenkaltaisten } \\
\text { sujumattomuuksien } \\
\text { kesto }\end{array}$ & $\begin{array}{l}\text { Kesto laskettiin } \\
\text { änkytyksenkaltaisen } \\
\text { sujumattomuuden } \\
\text { alkamisesta kohdesanan } \\
\text { onnistumiseen (esimerkkien } \\
\text { alleviivatut osuudet) }\end{array}$ & $\begin{array}{l}{[\underline{\text { ba-banaaneita ehkä] }}} \\
{[\underline{\text { te-te }(0.1)} \text { tehny kepeistä] }}\end{array}$ \\
\hline
\end{tabular}

* esimerkkinäytteet venytyksiin ja blokkeihin eivät ole tämän osatutkimuksen aineistosta, vaan kolmanteen osatutkimukseen kuuluvasta aivovamman saaneiden puhujien $(n=20)$ aineistosta (Penttilä, Korpijaakko-Huuhka \& Kent, 2018b) 


\section{TULOKSET}

Tähän tutkimukseen osallistuneiden 70 suomalaispuhujan puhenopeuden keskiarvo oli 3,77 tavua sekunnissa $(\mathrm{vv}=2,4-5,3, \mathrm{kh}=$ $0,69)$ ja artikulaationopeus 5,6 tavua sekunnissa $(3,9-6,8, \mathrm{kh}=0,69)$. Hiljaisten taukojen keskimääräinen kesto näytteissä oli 1,21 sekuntia $(0,1-5,8, \mathrm{kh}=0,98)$. Sujumattomuuspiirteistä tyypillisessä puheessa esiintyi useimmin epäröintejä, toiseksi eniten sanan toistoja ja kolmanneksi keskeytyksiä (taulukko 5).

Tutkimusaineistossa esiintyvät änkytyksenkaltaiset sujumattomuudet olivat yksittäisiä äänne- ja tavutoistoja. Niistä lasketun SLD-prosentin (stuttering like disfluencies) keskiarvo oli 0,20\% (vv = 0,00-3,70\%, $\mathrm{kh}=0,57)$ ja keston keskiarvo 0,11 sekuntia $(\mathrm{vv}=0,00-0,50, \mathrm{kh}=0,11)$.

\section{Sujumattomuusprosentti}

Aikuispuhujien sarjakuvakerronnan sujumattomuusprosentin keskiarvo (tyypillisten ja änkytyksenkaltaisten sujumattomuuksien määrän osuus sataa tavua kohden) oli 2,34 \% $(\mathrm{vv}=0,00-7,76 \%, \mathrm{kh}=2,25)$. Puhujien sujumattomuusprosentit eivät eronneet toisistaan tilastollisesti merkitsevästi vertailtaessa (Mann-Whitney $U$ ) sukupuolen $(U(68)=$ $606,-, 071, p=, 943)$ ja kätisyyden $(U(68)=$ $302,495, p=, 621)$ sekä iän (Kruskal-Wallis $H(3,70)=2,135, p=, 545)$, koulutustason $(H(3,70)=2,667, p=, 446)$ ja näytteen tavumäärän $(\mathrm{H}(6,70)=15,70, p=.058)$ perusteella muodostettuja ryhmiä toisiinsa.

Klusterianalyysin perusteella puhujat jakautuivat sujumattomuusprosentin mukaan viiteen ryhmään eli klusteriin (kuva 1). Puhujista $(\mathrm{N}=70) 17$ tuotti näytteen, jossa ei esiintynyt lainkaan sujumattomuuksia, kun hiljaisia taukoja ei laskettu sujumattomuuksiksi (klusteri 1). Tämän ryhmän tutkittavien puhe nimettiin erinomaisen sujuvaksi. Keskivertoa sujuvampaa puhe oli niin ikään 17:1lä tutkittavalla (klusteri 2), joiden puheen sujumattomuusprosentin keskiarvo oli 1,0\% (vaihteluväli 0,5-1,3\%, kh=0,23). Keskivertoisen sujuvasti puhuvien ryhmään (klusteri 3) kuului 22 tutkittavaa. Tämän ryhmän sujumattomuusprosentin keskiarvo oli 2,8\%

Taulukko 5. Sujumattomuuksien esiintymisjärjestys ja määrä

\begin{tabular}{|l|l|l|}
\hline Esiintymisjärjestys & Sujumattomuus & $\begin{array}{l}\text { Määrän keskiarvo } \\
(\mathrm{v}-\mathrm{v}=\text { vaihteluväli, kh }=\text { keskihajonta) }\end{array}$ \\
\hline $\mathbf{1 .}$ & epäröinti & $1,35(0,0-22,0, \mathrm{kh} 3,17)$ \\
\hline $\mathbf{2 .}$ & sanan toisto & $0,91(0,0-9,0, \mathrm{kh} 2,06)$ \\
\hline $\mathbf{3 .}$ & keskeytys & $0,85(0,0-14,0, \mathrm{kh} 1,80)$ \\
\hline $\mathbf{4 .}$ & korjaus & $0,84(0,0-10,0, \mathrm{kh} 1,63)$ \\
\hline $\mathbf{5 .}$ & interjektio & $0,61(0,0-10,0, \mathrm{kh} 2,02)$ \\
\hline $\mathbf{6 .}$ & fraasin toisto & $0,07(0,0-2,0, \mathrm{kh} 0,35)$ \\
\hline
\end{tabular}


$(1,5-4,1 \%$, kh = 0,79). Keskivertoa heikompaa sujuvuutta edusti vain kolmen tutkittavan näyte (klusteri 4), ja heidän sujumattomuusprosenttinsa keskiarvo oli 5,0 \% (4,9-5,2\%, $\mathrm{kh}=0,15)$. Sujuvuuden normaalivariaatioon kuuluivat myös 11 tutkittavan puhenäytteet, joissa esiintyi runsaasti sujumattomuuksia ( $\mathrm{ka}$ 6,4\%, v-v 5,6-7,8 \%, kh = 0,73; klusteri 5).

Klusterianalyysilla muodostettujen ryhmien näytteitä laadullisesti tarkasteltaessa havaittiin profiloitumista vallitsevan sujumattomuustyypin mukaan (taulukko 6). Keskivertoa sujuvammassa (klusteri 2) sekä keskivertoisen sujuvassa puheessa (klusteri 3) yleisin sujumattomuustyyppi oli epäröinti. Keskivertoa sujumattomammassa puheessa (klusteri 4) yleisin sujumattomuustyyppi oli korjaus. Puheessa, joka sisälsi runsaasti sujumattomuuksia (klusteri 5), yleisin tyyppi oli keskeytys.

Vaikka klusterit profiloituivatkin sujumattomuuksien laadun mukaan, sujumattomuuspiirteet eivät selkeästi erotelleet ryhmiä toisistaan tilastollisessa tarkastelussa. Tilastollisesti merkitsevästi sujumattomuuspiirteiltään toisistaan erosivat keskivertoa sujuvammat puhujat (klusteri 2) ja puhujat, joilla esiintyi runsaasti sujumattomuuksia (klusteri 5). Erottelevia piirteitä olivat epäröinti $(H(3,53), 2,803, p=0,030)$, keskeytys $(H(3$, $53), 3,615, p=0,002)$, sanatoisto $(H(3,53)$, $3,570, p=0,002)$ ja korjaus $(H(3,53), 3,970$,

Kuva 1. Sujumattomuusprosentin tarkastelu hierarkkisen klusterianalyysin muodostamien ryhmien mukaan

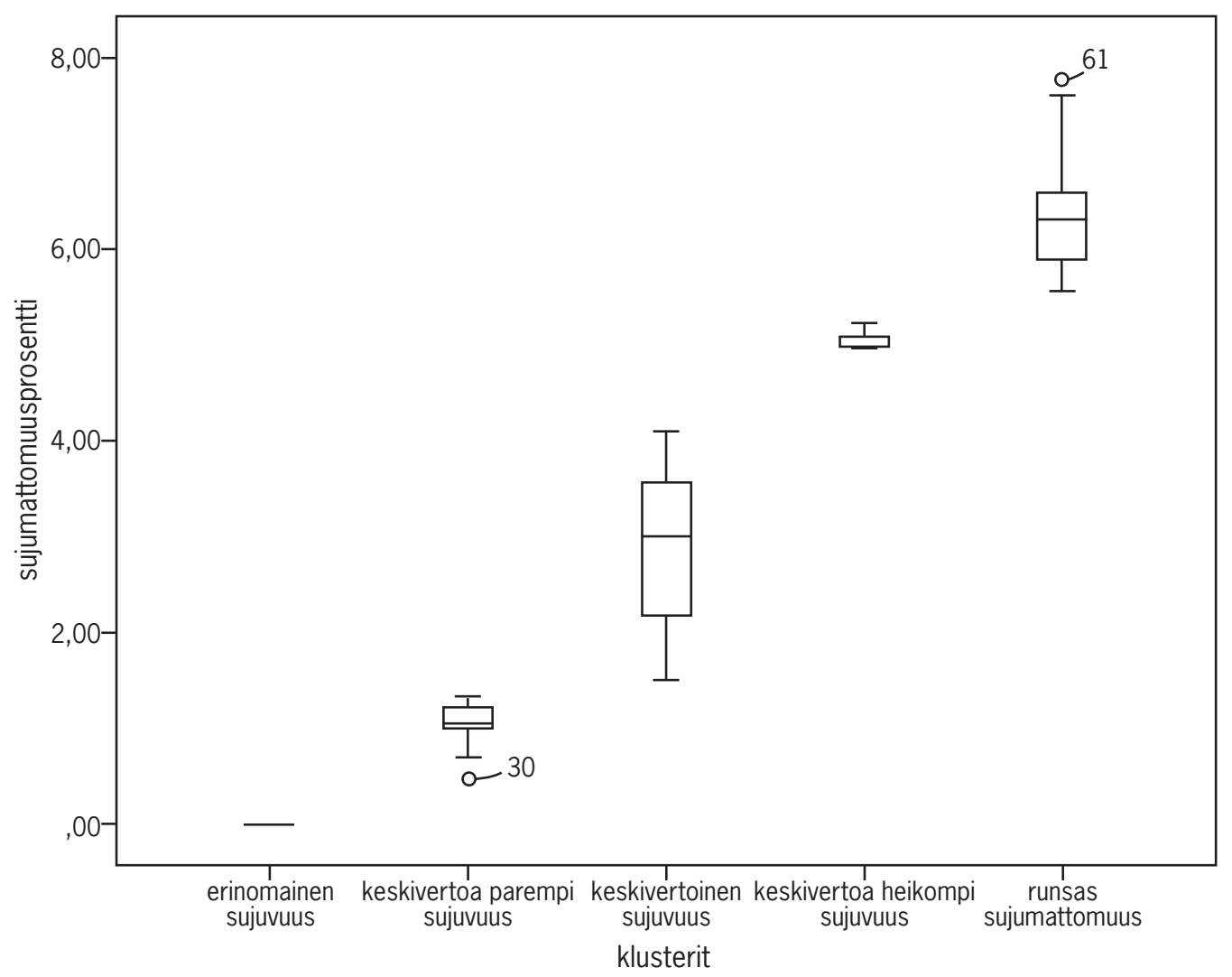


Taulukko 6. Sujumattomuustyyppien määrä eri klustereissa

\begin{tabular}{|c|c|c|c|c|c|c|c|c|}
\hline klusteri & & $\begin{array}{l}\text { sana- } \\
\text { toisto }\end{array}$ & $\begin{array}{l}\text { fraasi- } \\
\text { toisto }\end{array}$ & korjaus & keskeytys & interjektio & epäröinti & änkytys \\
\hline \multirow[t]{3}{*}{1} & ka & & - & & & . & & 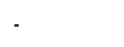 \\
\hline & $v-v$ & & & & & & & \\
\hline & kh & & & & & & & \\
\hline \multirow[t]{3}{*}{2} & ka & 0,18 & & 0,18 & 0,29 & 0,18 & 0,47 & 0,27 \\
\hline & $v-v$ & 0.2 & & 0.1 & 0.1 & 0.2 & 0.2 & 0.2 \\
\hline & kh & 0,53 & & 0,39 & 0,47 & 0,53 & 0,72 & 0,64 \\
\hline \multirow[t]{3}{*}{3} & ka & 0,86 & . & 0,68 & 0,91 & 0,41 & 1,32 & 0,23 \\
\hline & $v-v$ & 0.4 & & 0.2 & 0.3 & 0.5 & 0.10 & 0.3 \\
\hline & kh & 1,36 & & 0,72 & 0,81 & 1,22 & 2,15 & 0,75 \\
\hline \multirow[t]{3}{*}{4} & ka & 1,0 & 0,05 & 3,33 & 1,0 & 0,93 & 2,0 & - \\
\hline & $v-v$ & $1 \cdot 3$ & 0.1 & 2.5 & 1.2 & 1.4 & $1 \cdot 3$ & \\
\hline & kh & 0,93 & 0,21 & 1,53 & 0,82 & 0,58 & 1,00 & \\
\hline \multirow[t]{3}{*}{5} & ka & 3,94 & 0,36 & 3,01 & 4,91 & 4,61 & 4,72 & 0,82 \\
\hline & v-v & 2.9 & $1 \cdot 2$ & $2 \cdot 10$ & 3.13 & $4 \cdot 10$ & $4 \cdot 22$ & 0.4 \\
\hline & kh & 2,18 & 0,61 & 1,38 & 1,25 & 2,09 & 3,45 & 1,40 \\
\hline
\end{tabular}

$p=0,001)$, joita viidennen klusterin puhujilla oli enemmän kuin klusterin kaksi puhujilla. Lisäksi neljännen klusterin puhujilla oli korjauksia tilastollisesti merkitsevästi $(H(3,53)$, $3,432, p=0,004)$ enemmän kuin toisen klusterin puhujilla. Fraasitoistot, interjektiot ja änkytyksenkaltaiset äänne- ja tavutoistot eivät erotelleet klustereita tilastollisesti merkitsevästi toisistaan.

\section{Munttujien selitysvoima ja sujumattomuusfaktorit}

Regressioanalyysin perusteella sujumattomuusprosenttia selittivät tilastollisesti merkitsevästi korjaukset, sanojen toistot ja epäröinti (taulukko 7). Vaikka keskeytyksiä esiintyi puheessa sujumattomuuksista kolmanneksi useimmin (ks. taulukko 5), ei sen selitysvoima suhteessa sujumattomuusprosenttiin ollut tilastollisesti merkitsevä. Tässä aineistossa interjektiot, fraasien toistot tai änkytyksenkaltaiset sujumattomuudet eivät myöskään selittäneet sujumattomuusprosenttia.

Faktorianalyysi tuotti neljä komponenttia eli faktoria. Faktorianalyysissa Bartlettin sväärisyystestin arvo oli 0,000 (raja-arvo $<0,050$ ) ja Kaiserin testin arvo 0,788 (rajaarvo $>0,60$ ). Ensimmäisen faktorin ominaisarvo (engl. eigenvalue) oli 4.052 (raja-arvo $>1$ ), jolloin faktori selitti $57,9 \%$ muuttujien varianssista. Toisen faktorin ominaisarvo oli 1,005 , jolloin selitysaste oli 14,4\%. Kahdella faktorilla ominaisarvo oli siis suurempi kuin 1,0 , jolloin pelkästään nämä faktorit selittivät $72,3 \%$ muuttujien varianssista. Kolmannen faktorin ominaisarvo oli 0,790 , jolloin selitysaste oli varsin alhainen, noin $11 \%$. Neljännen 
Taulukko 7. Regressionanalyysi muuttujien vaikutuksesta sujumattomuusprosenttiin

\begin{tabular}{|l|l|l|l|l|l|l|}
\hline Muuttuja & B & Std.Error & Beta & t & Sig. & $\begin{array}{l}95,0 \% \\
\text { luottamusväli } \\
\text { B arvolle }\end{array}$ \\
\hline Epäröinti & 0,181 & 0,091 & 0,256 & 1,995 & $0,050^{*}$ & $-0,005 \cdot 0,364$ \\
\hline Sanan toisto & 0,480 & 0,137 & 0,439 & 3,500 & $0,001^{*}$ & $0,206 \cdot 0,755$ \\
\hline Keskeytys & $-0,441$ & 0,261 & $-0,354$ & $-1,687$ & 0,096 & $-0,963 \cdot 0,081$ \\
\hline Korjaus & 1,086 & 0,258 & 0,788 & 4,215 & $0,001^{*}$ & $0,571 \cdot 1,601$ \\
\hline Interjektio & $-0,143$ & 0,128 & $-0,128$ & $-1,119$ & 0,267 & $-0,398 \cdot 0,112$ \\
\hline Fraasin toisto & $-1,432$ & 0,760 & $-0,226$ & $-1,885$ & 0,064 & $-2,951 \cdot 0,086$ \\
\hline SLD & 0,578 & 0,338 & 0,145 & 1,713 & 0,102 & $0,214 \cdot 0,686$ \\
\hline
\end{tabular}

*SLD = stuttering like disfluencies eli änkytyksenkaltaiset sujumattomuudet

faktorin selitysaste jäi melko heikoksi, ollen ainoastaan $6,7 \%$ (ominaisarvo 0,466 ).

Ensimmäinen komponentti eli faktori muodostui keskeytyksistä ja korjauksista, ja faktori sai nimen ilmaisun muotoilu (taulukko 8). Toisen faktorin sujumattomuudet nimettiin ilmaisun suunnitteluun liittyviksi, sillä faktorin muodostivat interjektiot ja epäröinnit. Kolmannen faktorin muodostivat sanojen ja fraasien toistot, jotka liittyvät ilmaisun jatkuvuuden ylläpitoon. Neljännen faktorin änkytyksenkaltaiset äänne- ja tavutoistot nimettiin ilmaisun artikulointiin liittyviksi sujumattomuuksiksi.

Kun faktoreita tarkasteltiin summamuuttujina ja testattiin niiden selitysvoimaa uudella regressioanalyysilla, havaittiin, että vahvimmin sujumattomuusprosenttia selittivät $i l$ maisun muotoiluun liittyvät sujumattomuudet (keskeytykset ja korjaukset) ja toiseksi vahvimmin ilmaisun jatkuvuuden ylläpitoon liittyvät sujumattomuudet (sanan ja fraasin toisto) (taulukko 9). Summamuuttujamallissa suunnitteluun liittyvät sujumattomuudet (interjektio, epäröinti) eivät selittäneet sujumattomuusprosenttia, toisin kuin epäröinti yksittäisenä muuttujana tarkasteltaessa $(p=$ 0,050; taulukko 7).

\section{POHDINTA}

Tässä tutkimuksessa puheen sujuvuus asettui terveillä aikuisilla $(\mathrm{N}=70)$ jatkumolle, jossa yhtä äripäätä edustivat erinomaisen sujuvat puhujat $(n=17)$ ja toista puhujat, joiden puheessa esiintyi runsaasti sujumattomuuksia $(n=11)$. Jatkumolle asettuneet puhujat eivät pelkästään eronneet sujumattomuusprosentin mukaan ( $\mathrm{vv}=0,0-7,8 \%$ ), vaan myös sujumattomuustyyppi vaihteli. Sujuvimmassa puheessa esiintyi useimmin ilmaisun suunnitteluun liittyvää epäröintiä, mutta sujumattomuusprosentin kasvaessa ilmaisun muotoiluun liittyvät korjaukset yleistyivät, ja kaikista sujumattomimmassa puheessa keskeytykset olivat tyypillisin sujumattomuuspiirre.

Yleisin sujumattomuustyyppi tässä aineistossa oli epäröinti, ja se selittikin parhaiten 
Taulukko 8. Sujuvuuden muuttujista muodostuneet komponentit eli faktorit

\begin{tabular}{|c|c|c|c|c|}
\hline \multicolumn{5}{|c|}{ Faktorit } \\
\hline & $\begin{array}{l}\text { Ilmaisun } \\
\text { muotoilu }\end{array}$ & $\begin{array}{l}\text { Ilmaisun } \\
\text { suunnittelu }\end{array}$ & \begin{tabular}{|c} 
Ilmaisun \\
jatkuvuuden ylläpito
\end{tabular} & Ilmaisun artikuloint \\
\hline \multicolumn{5}{|l|}{ korjaus } \\
\hline \multicolumn{5}{|l|}{ keskeytys } \\
\hline \multicolumn{5}{|l|}{ interjektio } \\
\hline epäröinti &, 519 & 648 & & \\
\hline fraasin toisto & ,451 & &, 808 & \\
\hline sanan toisto & &, 578 &, 687 & \\
\hline SLD & & & &, 984 \\
\hline
\end{tabular}

*SLD = stuttering like disfluencies

Taulukko 9. Summamuuttujien vaikutus sujumattomuusprosenttiin

\begin{tabular}{|l|l|l|l|l|l|l|}
\hline Muuttuja & B & Std.Error & Beta & $\mathrm{t}$ & Sig. & $\begin{array}{l}95,0 \% \\
\text { luottamusväli B } \\
\text { arvolle }\end{array}$ \\
\hline muotoilu & 0,266 & 0,082 & 0,396 & 3,256 & $0,002^{*}$ & $0,103 \cdot 0,429$ \\
\hline suunnittelu & 0,030 & 0,063 & 0,063 & 0,477 & 0,365 & $-0,096 \cdot 0,157$ \\
\hline jatkuvuus & 0,283 & 0,129 & 0,289 & 2,193 & $0,032^{*}$ & $0,025 \cdot 0,541$ \\
\hline artikulointi & 0,314 & 0,263 & 0,111 & 1,192 & 0,238 & $-0,212 \cdot 0,839$ \\
\hline
\end{tabular}

sujumattomuusprosenttia korjausten ja sanatoistojen lisäksi. Epäröinti oli sujumattomuuspiirteenä myös sujuvuuden ääripäitä (klusterit 2 ja 5) tilastollisesti erottava tekijä. Fraasitoistot, interjektiot ja änkytyksenkaltaiset sujumattomuudet eivät erotelleet ryhmiä, eivätkä ne itsenäisinä muuttujina vaikuttaneet sujumattomuusprosenttiin tilastollisesti merkitsevällä tavalla.

Sujumattomuuksista muodostui neljä faktoria: sujumattomuudet, jotka liittyivät 1) kielelliseen muotoiluun, 2) viestin suunnitteluun, 3) viestin jatkuvuuden ylläpitoon ja
4) artikulaatioon. Sujumattomuusprosenttia selittivät parhaiten sujumattomuudet, jotka liittyivät kielelliseen muotoiluun sekä ilmaisun jatkuvuuden ylläpitoon.

\section{Tavallista sujumattomuutta}

Tässä tutkimuksessa terveiden puhujien puhenopeuden keskiarvo sarjakuvakerronnassa (3,77 tavua sekunnissa) oli yhdenmukainen aiempiin suomalaisiin tutkimuksiin verrattuna (3,3 tavua/s; Lehtonen, 1978, 3,53 tavua/s; Moore, 1991). Myös artikulaationopeuden 
$(\mathrm{ka}=5.6$ tavua sekunnissa $)$ suhteen tulokset vahvistivat aiempien tutkimusten tuloksia (5,3; Lehtonen, 1978; 5,04; Moore, 1991). Tässä aineistossa puhenopeuden vaihteluväli oli kuitenkin melko laaja (2.4-5.3 tavua sekunnissa), ja tätä suurta vaihtelua voi selittää yksin käytetty puhetehtävä, sarjakuvakerronta. Visuaaliseen aineistoon nojaavassa kerronnassa puhuja joutui muodostamaan kielellisen tuotoksen rajatusta ja mahdollisesti itselle vieraasta aiheesta sekä tiettyjä sääntöjä noudattaen, jolloin esityksen suunnittelu saattaa viedä paljon aikaa eli tuottaa runsaasti taukoja (Korpijaakko-Huuhka \& Aulanko, 1994). Korpijaakko-Huuhka ja Aulanko (1994) mittasivat tässäkin tutkimuksessa käytettyyn sarjakuvakerrontatehtävään perustuvasta aineistostaan sekä suunnittelutaukojen että ilmausten sisäisten hiljaisten taukojen kestoja ja havaitsivat, että pidempien ilmauksien rajoilla tauot kestivät keskimäärin jopa yli 2 sekuntia, kun ne ilmausten sisällä olivat tyypillisesti alle sekunnin mittaisia. Koska puhenopeus on sidoksissa taukoihin, tässä tutkimuksessa havaittu hiljaisten taukojen keston laaja variaatio $(0,1-5,8 \mathrm{~s}, \mathrm{ka}=1,21 \mathrm{~s}, \mathrm{kh}=0,98)$ selitti osaltaan puhujien puhenopeuksien eroja.

Aiemmissa tutkimuksissa yleisintä sujumattomuustyyppiä on kuvattu joko täytetyksi tanoksi (McDougall \& Duckworth, 2017; Moniz ym., 2014; Schachter, Christenfeld, Ravina \& Bilous, 1991), täytesanaksi (Bortfeld ym., 2001) tai interjektioksi ja epäröinniksi (Duchin \& Mysak, 1987; Roberts ym., 2009; Searl ym., 2002). Tutkijat, jotka käyttävät termiä täytetty tauko, viittaavat joko ainoastaan epäröinteihin $(/ \mathrm{mm} /$, /öö/) tai niiden lisäksi myös interjektioihin (/no/, / niiku/), jolloin joissain tapauksissa täytetty tauko käsitteenä voidaan mieltää epäröintien ja interjektioiden kattotermiksi (esim. Moniz ym., 2014). Toisaalta interjektioita kuvataan valtaosassa tutkimuksia esimerkeillä $/ \mathrm{mm} /$, / öö/, jotka tuovat herkästi mieleen epäröinti- ääntelyn, mutta myös diskurssipartikkeleita (/ no/,/niiku/) käytetään kuvaamaan interjektioita. Sekaannusta aiheuttaa myös täytesana termin käyttö, jolla yleensä kuvataan niin epäröintiääntelyä, interjektioita huudahdusten muodossa, mutta myös kokonaisia diskurssipartikkeleita (Fox Tree, 1995). Kaikki edellä mainitut termit ovat toistensa synonyymeja pienillä tyylieroilla, mutta yhteistä kaikille on tarve märritellä epäröintiin viittaavat ääntelyt ja informaatioarvoltaan köyhemmät ilmaisut, kuten interjektiot ja diskurssipartikkelit sujumattomuuksiksi. Tässä tutkimuksessa termien epäjohdonmukaista käyttöä pyrittiin välttämään, ja siksi aineistosta poimittiin erikseen sekä epäröinnit että interjektiot, jotka pyrittiin menetelmäluvussa kuvaamaan selkein esimerkein (taulukko 3). Tässä tutkimuksessa esiintyvyydeltään yleisin sujumattomuus oli epäröinti, joka selitti myös tilastollisesti merkitsevästi sujumattomuusprosenttia itsenäisenä muuttujana ja klustereita erottelevana tekijänä, mutta ei yhdistettynä interjektioibin.

Kun interjektioita tarkasteltiin tässä tutkimuksessa erikseen, havaittiin, että ne eivät olleet tilastollisesti merkitseviä sujumattomuusprosentin selittäjiä, eivätkä näin ollen erotelleet puhujaryhmiäkään tilastollisesti toisistaan. Joissain aiemmissa tutkimuksissa (mm. Roberts ym., 2009; Searl ym., 2002) interjektiot on todettu yleisimmäksi sujumattomuustyypiksi, mikä todennäköisesti selittyy käsitteiden määrittelyn epäjohdonmukaisuudella sekä eri tutkijoiden epäsystemaattisella tavalla käyttää samasta asiasta eri termiä. Vaikka tässä tutkimuksessa interjektiot ja epäröinnit muodostivat luonnollisen summamuuttujan faktorianalyysissa, ei faktorin rooli sujumattomuusprosenttia selittävänä tekijänä ollut tilastollisesti merkitsevä. Näin ollen voimme ajatella, että tyypillisessä puheessa interjektioita ei tulisi käsitellä sujumattomuuksina lainkaan vaan luonnollisina diskurssipartikkeleina. Toisaalta häiriinty- 
neessä puheessa, kuten esimerkiksi änkytyksessä, puhuja voi pyrkiä interjektioiden avulla välttelemään, viivyttämään tai peittelemään änkytystä, jolloin interjektioiden roolia on hedelmällisempi pohtia osana änkytyksen sekundäärireaktioita tai jopa sen primääriilmentymänä (Yaruss, 2004). Siksi interjektioiden esiintyvyyttä ja merkitystä olisi tärkeää tarkastella erityisesti häiriintyneessä puheessa, esimerkiksi aivovamman tai aivoverenkiertohäiriön jälkeen.

Sanan toisto oli toiseksi yleisin sujumattomuuden tyyppi, joka selitti tilastollisesti myös sujumattomuusprosenttia. Faktorianalyysissa se muodosti komponentin yhdessä fraasien toistojen kanssa, ja tämä faktori nimettiin kuvaamaan ilmaisun jatkuvuuden ylläpitoa. Fraasien toistoa esiintyi määrällisesti vähiten koko aineistossa, eikä se itsenäisenä muuttujana erotellut puhujaryhmiä tai vaikuttanut sujumattomuusprosenttiin. Kuitenkin fraasien toiston ja sanatoiston muodostama faktori selitti sujumattomuusprosenttia tilastollisesti merkitsevästi. Sanan ja fraasin toistolla onkin merkityksensä erilaisissa diskursseissa. Niillä voidaan aloittaa puhunnos alusta tai tehostaa aiemmin sanottua (Clark \& Wasow, 1998; Heike, 1981). Lingvistiikassa käytetään termiä "repair" kuvamaan sanan toistoa, täydennystä tai uutta aloitusta, siis niin sanottua "uudelleenmuotoilua" (Levelt, 1983; Fox Tree \& Clark, 1997). Levelt (1983) mieltää "repairin" sujuvaksi osaksi puhetta, ja myös tässä aineistossa nousi esiin sanatoiston merkitys suunniteltuna sujumattomuutena, joka voidaan tulkita pyrkimykseksi ylläpitää kerronnan jatkuvuutta sanahaun ja kielellisen suunnittelun aikana, kuten alla olevista tyyppiesimerkeistä 1-3 käy ilmi.

\section{Esimerkki 1. Sanan toisto}

on sitten (1.0) harakoita ne on tullu (.) bäiribtemmään sitä (0.5) sitä tota viljelytoubua
Esimerkki 2. Sanan toisto

siellähän ne varikset taas oli jopa siellä sen (1.2) sen (1.2) variksenpelättimen (0.4) päällä

Esimerkki 3. Sanan toisto

hän kaivaa (0.5) kaivaa (0.9) kuoppia (1.5) kuoppiaja (0.5) kuoppiakasvimaallaja (1.5) saa istutetuksi (0.7) siemenet (1.5) mutta sitten bän huomaakin että (0.5) tulee varislauma

Kolmanneksi yleisin tämän aineiston sujumattomuuden tyyppi määrällisesti tarkasteltuna oli keskeytys. Kun ihminen keskeyttää puhunnoksen, voidaan ajatella, että hän on tunnistanut virheen (Blackmer \& Mitton, 1991). Virhe voi olla syntynyt joko suunnittelun aikana tai liittyen artikulaatioprosessiin (Levelt, 1989; Lickley, 2015). Esimerkissä 4 keskeytetyn ilmaisun virheellisyys on mahdollisesti tunnistettu jo suunnitteluvaiheessa, sillä puhuja pitää tauon ennen korjausta, ja keskeytetty ilmaisu eroaa korjatusta tuotoksesta. Esimerkeissä 5 ja 6 virhe on taas todennäköisesti tunnistettu vasta artikulointivaiheessa, sillä sen korjaus tapahtuu välittömästi ilman taukoa, ja virhe on äänteellisesti lähellä korjattua tuotosta.

\section{Esimerkki 4. Keskeytys}

siispä tää mies aik (0.2) hän hakee tuolta (0.7) varastosta (0.8)

\section{Esimerkki 5. Keskeytys}

ja tadaa hieno variksenpelätin oli var valmis (2.3)

\section{Esimerkki 6. Keskeytys}

tekeekin tommosen (0.5) öö pelotte siihen pelottimen (0.5)

Korjaukset ja keskeytykset muodostivat faktorianalyysissa vahvan sujumattomuusprosenttia selittävän komponentin. Terveiden puhujien kohdalla on luonnollista ajatella, 
että keskeytyksen jälkeen puhuja pyrkii korjaamaan tuotoksen, ja lisäksi korjaus on yleensä onnistunut, mutta häiriintyneessä puheessa ei näin välttämättä aina ole (Liss, 1998; Milroy \& Perkins, 1992; Oomen, Postma \& Kolk, 2001). Olisikin mielenkiintoista tarkastella Leveltin (1983) mallin mukaan terveiden puhujien itsekorjausjaksoja esimerkiksi tämän tutkimuksen aineistolla. Myös keskeytysten ja korjausten, sekä muiden sujumattomuuksien prosodinen analyysi olisi mielekäs jatkotutkimusaihe sujuvuuden kuulonvaraiseen tunnistukseen liittyen (Moniz ym., 2014).

Sujumattomuusprosentin keskiarvo (2,34 \%) oli tässä aineistossa suhteellisen matala, verrattuna esimerkiksi Robertsin työryhmän (2009) raportoimaan englanninkielisten puhujien sujumattomuusprosenttiin $(6,4-7,8$ $\%)$. Huomionarvoista kuitenkin on, että 20 prosentilla tämän tutkimuksen tutkittavista sujumattomuusprosentti oli yli 5. Vertailu muihin tutkimuksiin on hankalaa puhetehtävien erilaisuuden vuoksi, sillä esimerkiksi Robertsin ja kollegoiden (2009) tutkimuksen aineisto koostui erilaisista spontaanipuheen tehtävistä. Jatkotutkimuksena olisi siis mielenkiintoista tarkastella tämän tutkimuksen puhujien sujumattomuusprosentin vaihtelua eri puhetehtävissä, kuten esimerkiksi toistopuheessa ja spontaanipuheessa. Koska puhe on ensisijaisesti tarkoitettu toista ihmistä varten, jolloin sujumattomuuksilla voidaan nähdä olevan pragmaattinen funktio osana luonnollista keskustelua, olisi tärkeä tutkia sujuvuutta erityisesti diskursseissa monologien sijaan.

Poikkeuksellista verrattuna aiempiin tutkimuksiin oli tässä tutkimuksessa se, että ensimmäiseen klusteriin ryhmittyneillä puhujilla $(n$ $=17$ ) ei esiintynyt lainkaan sujumattomuuksia, kun hiljaisia taukoja ei pidetty sujumattomuuksina. Nämä seitsemäntoista tutkittavaa olivat ikähaarukaltaan 24-66 vuotiaita. Heidän koulutustasonsa vaihteli seuraavasti: pe- ruskoulu $(\mathrm{n}=2)$, toisen asteen koulutus $(\mathrm{n}=$ 5), korkeakoulututkinto $(\mathrm{n}=8)$, ylempi korkeakoulututkinto $(\mathrm{n}=2)$. Esimerkin 7 näyte kuuluu puhujalle, joka ryhmittyi ensimmäiseen klusteriin. Näyte on tutkimusaineiston lyhyin (97 tavua), mutta tässä aineistossa tavumärä ei vaikuttanut sujumattomuusprosent$\operatorname{tiin}(H(6,70)=15,70, p=.058)$. Myöskään Robertsin työryhmän (2009) tutkimuksessa tavumäärällä (300/500/800/1000) ei havaittu olevan tilastollista vaikutusta sujumattomuusprosenttiin. Tavumäärän ja koulutustaustan sijaan, mahdollisia selittäviä tekijöitä täysin sujuvan puhenäytteen taustalla voivat olla hyvät kerronnalliset taidot, kyky rakentaa looginen kertomus tai harkittu kerrontatyyli.

Esimerkki 7. Kerrontanäyte, jossa ei esiinny sujumattomuuksia

ja (.) haaveilee mielessä̈̈n (0.7) herkullisesta (0.2) ja valtavasta sadosta (1.3) kuten kurpitsoista ja kurkuista ja tomaateista (0.3) kumminkin (0.4) varikset (.) hyökkäävät viljelysmaalle ja syövät maajussin siemenet (1.0) kaikki on mennyttä (0.7) sitten mies päättää rakentaa variksenpelättimen (0.5) pelottaakseen varikset tiehensä (1.5) mutta sekä̈n ei toimi

\section{Menetelmän pohdinta}

Tämän tutkimuksen yksi tavoite oli luoda verrokkiaineisto terveiden puhujien sujuvuudesta kliinisen työn ja tulevien tutkimusten tueksi. Siksi aineiston koko pyrittiin kasvattamaan mahdollisimman suureksi yhden ihmisen työmäärään sopeutettuna, ja tässä onnistuttiin $(N=70)$. Aineiston käyttöä verrokkiaineistona puoltaa myös tutkittavien laaja eri murrealueiden edustus, sillä joukossa oli tutkittavia eri puolilta Suomea (Joensuu, Tampere, Kouvola, Kuopio, Kajaani, Helsinki). Suurin osa puhujista kuului ikäryhmään 29-49 vuotta $(n=47)$, mutta aineistoon 
saatiin luonnollista variaatiota myös ikääntyneistä (66-89-vuotiaat; $n=6)$ ja nuoremmista (18-28-vuotiaat; $n=8$ ) puhujista. Myös puhujien koulutustausta vaihteli (taulukko 2).

Kuvakerronta voidaan nähdä semispontaanina puhetehtävänä, sillä spontaanipuheen sijaan puhujalla on käytössään kuvatuki (Lind, Kristoffersen, Moen \& Simonsen, 2009). Kuvat siis rajaavat kertomuksen sisältöä, sanastoa ja kestoa, mikä tekee kuvakerrontaan perustuvien aineistojen vertailun niin kliinisessä kuin tutkimustyössäkin luotettavammaksi verrattuna esimerkiksi spontaanipuhetta sisältävien aineistojen vertailuun, joissa topiikilla on suuri rooli. Logopedisesta näkökulmasta kerrontatehtävän käyttö on aineistona mielekästä (Mäkinen \& Kunnari, 2009), sillä kerronta tuo hyvin esiin puhujan kielelliset taidot $(k o g$ nitivinen sujuvuus; Segalowitz, 2010) sekä kyvyn sovittaa yhteen näitä taitoja (ilmaisun sujuvuus; Segalowitz, 2010). Variksenpelätinkertomus on aineistonkeruutehtävänä sangen paljon käytetty, ja siksi se valittiin myös tämän tutkimuksen elisitointikeinoksi (mm. Korpijaakko-Huuhka, 2003; Korpijaakko-Huuhka \& Aulanko, 1994; Korpijaakko-Huuhka \& Lind, 2012).

Aineisto päätettiin rajata sisällöllisesti eikä tietyn tavumäärän tai keston perusteella siten, että kerrontanäyte kattoi variksenpelätinkertomuksen kuvat 2-7. Penttilän ym. (2018a) tutkimuksessa semanttinen rajaus lyhensi näytteiden kestoa ja täten kuulijaraadin työmäärää, sekä helpotti audioaineistojen vertailua. Tässä tutkimuksessa kvantitatiiviset analyysit tehtiin näistä 70 terveen puhujan semanttisesti rajatuista audionäytteistä (Penttilä ym., 2018a), jotta suuren aineiston analysointi olisi työmäärältään kohtuullinen yhdelle ihmiselle. Saman aineiston käytön nähdään palvelevan myös jatkotutkimusta, jos kuulijaraadin arvioita ja tässä tutkimuksessa mitattuja sujumattomuusprosentteja halutaan verrata toisiinsa.
Kuitenkaan semanttinen rajaus ei ehkä ollut paras mahdollinen tämän osatutkimuksen tarkoituksiin, sillä se lyhensi näytteitä ja lisäsi tavumäärän variaatiota tutkittavien välillä. Koska sarjakuvakerronta tuotti luonnostaan eri pituisia kertomuksia, olisi näytteet voinut rajata lyhimmän näytteen mukaan. Jos taas aineiston tavumäärää olisi haluttu kasvattaa lyhimpien näytteiden osalta, tutkija olisi joutunut houkuttelemaan puhujaa tuottamaan lisää puhetta. Tämä olisi heikentänyt kerrontanäytteiden autenttisuutta, ja riski aineiston muuttumisesta haastattelumaiseksi tai nimeämistehtävän kaltaiseksi olisi ollut suuri.

Sarjakuvakerronta tehtävänä tuottaa siis itsessään eri mittaisia kertomuksia, koska ihmisten kerrontatyylit vaihtelevat. Silti lyhimmätkin kertomukset olivat tässä tutkimuksessa sisällöltään yhtä asiallisia, kuin pidemmät kertomukset, eikä tavumäärällä ollut vaikutusta sujumattomuusprosenttiin.

\section{LOPUKSI}

Tämä tutkimus on ensimmäinen laaja suomalainen tutkimus terveiden aikuisten puheen sujuvuudesta. Sen tulokset vahvistavat ajatusta puheen sujuvuudesta jatkumona sekä tuovat esiin sujumattomuuksien laajan variaation niin määrällisesti kuin laadullisestikin. Tutkimuksen tulokset osoittavat jälleen kerran, että sujuva puhe on luonnostaan sujumatonta, jolloin voimme pitää sujuvuutta pikemminkin odotusarvona, itsestäänselvyyden sijaan.

Puheterapeuttisessa kuntoutuksessa tulisi muistaa, että kuulostaakseen luonnolliselta puhujan puheessa täytyy olla tyypillisiä sujumattomuuksia. Tämä voi olla esimerkiksi änkytyskuntoutuksessa tärkeä kuntoutuksen tavoite: siis vähentää änkytyksenkaltaisia sujumattomuuksia ja lisätä tyypillisiä. Tämän tutkimuksen aineisto tuo tietoa sujuvuuden normaalivariaatiosta sekä häiriödiagnostiikan että kuntoutustavoitteiden asettamisen tuek- 
si. Lisäksi tutkimus toimii vertailuaineistona tuleville puheen häiriöitä tarkasteleville tutkimuksille.

\section{LÄHTEET}

Allwood, J., Nivre, J. \& Ahlsén, E. (1990). Speech management: On the non-written life of speech. Nordic Journal of Linguistics, 13, 3-48.

Ambrose, N. \& Yairi, E. (1999). Normative disfluency data for early childhood stuttering. Journal of Speech, Language, and Hearing Research, 42, 895-909.

Arnold, J., Fagnano, M. \& Tanenhaus, M. (2003). Disfluencies signal thee, um, new information. Journal of Psycholinguistic Research, 32, 25-36.

Bard, E., Lickley, R. \& Aylett, M. (2001). Is disfluency just difficulty? Disfluency in Spontaneous Speech (DiSS '04), (s. 97-100). Edinburgh, Scotland.

Bell, L., Eklund, R. \& Gustafsson, J. (2000). A comparison of disfluency. Distribution in a unimodal and a multimodal speech interface. Proceedings of ICSLP 2000, $6^{\text {th }}$ International Conference on Spoken Language Processing (s. 626-629). Beijing, China.

Blackmer, E. \& Mitton, J. (1991). Theories of monitoring and the timing of repairs in spontaneous speech. Cognition, 39, 173-194.

Boersma, P. \& Weenink, D. (2010). Praat: Doing phonetics by computer. Version 5.1.43. http:// www.praat.org

Bortfeld, H. Leon, S., Bloom, J., Schober, M. \& Brennan, S. (2001). Disfluency rates in conversation: Effects of age, relationship, topic, role, and gender. Language and Speech, 44, 123-147.

Brennan, S. \& Schrober, M. (2001). How listeners compensate for disfluencies in spontaneous speech? Journal of Memory and Language, 44, 274-296.

Brown, S., Ingham, R., Ingham, J., Laird, A. \& Fox, P. (2005). Stuttered and fluent speech production: an ALE meta-analysis of functional neuroimaging studies. Human Brain Mapping, 25, 105-117.

Clark, C., Conture, E., Walden, T. \& Lambert, W. (2015). Speech-Language dissociations, distractibility, and childhood stuttering. American Journal of Speech-Language Pathology, 24,
480-503.

Clark, H. \& Fox Tree, J. (2002). Using uh and um in spontaneous speaking. Cognition, 84, 73-111.

Clark, H. \& Wasow, T. (1998). Repeating words in spontaneous speech. Cognitive Psychology, 37, 201-242.

Duchin, S. \& Mysak, E. (1987). Disfluency and rate characteristics of young adult, middle-aged, and older males. Journal of Communication Disorders, 20, 245-257.

Fox Tree, J. (1995). The effects of false starts and repetitions on the processing of subsequent words in spontaneous speech. Journal of Memory and Language, 34, 709-738.

Fox Tree, J. \& Clark, H. (1997). Pronouncing "the" as "thee" to signal problems in speaking. Cognition, 62, 151-167.

Goberman, A., Blomgren, M. \& Metzger, E. (2010). Characteristics of speech disfluency in Parkinson disease. Journal of Neurolinguistics, 23, 470-478.

Gregory, H. (1993). A clinician's perspective: Comment of identification of stuttering, prevention and early intervention. Journal of Fluency Disorders, 18, 389-402.

Guitar, B. (2006). Stuttering: An integrated approach to its nature and treatment. Baltimore, MD: Lippincott, Williams \& Wilkins.

Heike, A. (1981). A content-processing view of hesitation phenomena. Language and Speech, 24, 147-160.

Horton, W. \& Gerrig, R. (2005). The impact of memory demands on audience design during language production. Cognition, 96, 127-142.

Johnson, W. (1961). Measurements of oral reading and speaking rate and disfluency of adult male and female stutterers and nonstutterers. The Journal of Speech and Hearing Disorders, 7 , $1-20$.

Kasl, S. \& Mahl, G. (1987). Speech disturbances and experimentally induced anxiety. Teoksessa G. Mahl (toim.), Explorations in nonverbal and vocal behavior, (s. 203-213). Hillsdale, NJ: Erlbaum.

Kent, R. D. (2000). Research on speech motor control and its disorders: A review and prospective. Journal of Communication Disorders, 33, 391-428.

Kormos, J. \& Dénes, M. (2004). Exploring meas- 
ures and perceptions of fluency in the speech of second language learners. System, 32, 145-164.

Korpijaakko-Huuhka, A-M. (2003). Kyllä se lintupelotintaulujuttu siinä nyt on käsittelyssä. Afaattisten pubujien kielellisiä valintoja sarjakuvatehtävässä. Väitöskirja. Helsinki: Helsingin yliopiston fonetiikan laitoksen julkaisuja 46.

Korpijaakko-Huuhka, A.-M. \& Aulanko, R. (1994). Auditory and acoustic analysis of prosody in the clinical evaluation of narrative speech. Teoksessa R. Aulanko \& A.-M. Korpijaakko-Huuhka (toim.), Proceedings of the Third Congress of the International Clinical Phonetics and Linguistic Association (s. 91-98). Helsinki, Finland: Helsingin yliopiston fonetiikan laitoksen julkaisuja.

Korpijaakko-Huuhka, A-M. \& Lind, M. (2012). The impact of aphasia on textual coherence: Evidence from two typologically different languages. Journal of Interactional Research in Communication Disorders, 3, 47-70.

Laakso, M. (1997). Self-initiated repair by fuent aphasic speakers in conversation. Väitöskirja. Studia Fennica Linguistica 8. Helsinki: Suomalaisen Kirjallisuuden Seura.

Lee, H. Gayraud, F., Hirsh, F. \& Barkat-Defradas, M. (2011). Speech dysfluencies in normal and pathological aging: A comparison between Alzheimer patients and healthy elderly subjects. The $17^{\text {th }}$ International Congress of Phonetic Sciences (ICPhs). Hong Kong, China, 1174-1177.

Lehtonen, J. (1978). On the problems of measuring fluency. AFinL An vuosikirja, 53-68.

Levelt, W. (1983). Monitoring and self-repair in speech. Cognition, 14, 41-104.

Lickley, R. (2001). Dialogue moves and disfluency rates. Proceedings of Disfluency in Spontaneous Speech (DiSS '01), Edinburgh, Scotland, 93-96.

Lickley, R. (2015). Fluency and disfluency. Teoksessa M. Redford (toim.), The handbook of speech production (s. 445-473). Wiley-Blackwell.

Lind, M., Kristoffersen, K., Moen,I. \& Simonsen, H. (2009). Semi-spontaneous oral text production: Measurements in clinical practice. Clinical Linguistics \& Phonetics, 23, 872-886.

Liss, J. (1998). Error-revision in the spontaneous speech of apraxic speakers. Brain and Language, 62, 342-360.

Logan, K. (2015). Fluency Disorders. San Diego: Plural Publishing
Lundgren, K., Helm-Estabrooks, N. \& Klein, R. (2010). Stuttering following acquired brain damage: A review of the literature. Journal of Neurolinguistics, 23, 447-454.

Lutz, K. \& Mallard, A. (1986). Disfluencies and rate of speech in young adult nonstutterers. Journal of Fluency Disorders, 11, 307-316.

McCauley, R. (1989). Measurement as a dangerous activity. Journal of Speech Language Pathology and Audiology, 13, 29-32.

McDougall, K. \& Duckworth, M. (2017). Profiling fluency: An analysis of individual variation in disfluencies in adult males. Speech Communication, 95, 16-27.

Milroy, L. \& Perkins, L. (1992). Repair strategies in aphasic discourse: Towards a collaborative model. Clinical Linguistics \& Phonetics, 6, $27-40$.

Moniz, H., Batista, F., Mata, A. \& Trancoso, I. (2014). Speaking style effects in the production of disfluencies. Speech Communication, 65, 20-35.

Moore, K. (1991). Speech rate, phonation rate, and pauses in cartoon and sports narrations. Teoksessa R. Aulanko \& M. Leiwo (toim.), Studies in Logopedics and Phonetics 2, (135143), Helsingin yliopiston fonetiikan laitoksen julkaisuja.

Moore, K. \& Korpijaakko-Huuhka, A-M. (1996). The clinical assessment of Finnish fluency. Teoksesssa M. Ball \& M. Duckworth (toim.), Advances in Clinical Phonetics. Studies in Speech Pathology \& Clinical Linguistics, 6, (171-196). Amsterdam: John Benjamins.

Mäkinen, L. \& Kunnari, S. (2009). Lasten kerrontataitojen arvioiminen. Puhe ja kieli, 29, 103-120.

O'Connel. D. \& Kowal, S. (2005). Uh and um revisited: are they interjections for signaling delay? Journal of Psycholinguistic Research, 34, 555-576.

Oomen, C., Postma, A., \& Kolk, H. (2001). Prearticulatory and postarticulatory self-monitoring in Broca's aphasia. Cortex, 37, 627-641.

Oviatt, S. (1995). Predicting spoken disfluencies during human-computer interaction. Computer, Speech and Language, 9, 19-35.

Penttilä, N., Korpijaakko-Huuhka, A.-M. \& Kent, R. (2018a). Auditory-perceptual assessment of fluency in typical and neurologically disordered 
speech. Journal of Speech, Language, and Hearing Research, 61, 1086-1103.

Penttilä, N., Korpijaakko-Huuhka, A.-M. \& Kent, R. (2018b). Disfluency clusters in speakers with and without neurogenic stuttering following traumatic brain injury. Journal of Fluency Disorders. Arvioitavana oleva käsikirjoitus.

Postma, A. \& Kolk, H. (1993). The covert repair hypothesis: Prearticulatory repair process in normal and stuttered disfluencies. Journal of Speech and Hearing Research, 36, 472-478.

Roberts, P., Meltzer, A. \& Wilding, J. (2009). Disfluencies in non-stuttering adults across sample lengths and topics. Journal of Communication Disorders, 42, 414-427.

Schachter, S., Christenfeld, N., Ravina, B. \& Bilous, F. (1991). Speech disfluency and the structure of knowledge. Journal of Personality and Social Psychology, 60, 362-367.

Searl, J., Gabel, R. \& Fulks, S. (2002). Speech disfluency in centenarians. Journal of Communication Disorders, 35, 383-392.

Segalowitz, N. (2010). Cognitive bases of second language fluency. New York: Routledge.

Ullakonoja, R. (2008). Pausing as an indicator of fluency in the Russian of Finnish learners. Teoksessa P. A. Barbosa, S., Madureira \& C. Reis (toim.), Proceedings of the Speech Prosody 2008 Conference, Campinas, Brazil, (s. 339-342), Sao Paulo: Editora RG/CNPq.
Van Borsel, J. (2014). Acquired stuttering: A note on terminology. Journal of Neurolinguistics, 27, 41-49.

Van Lieshout, P., Bose, A., Square, P. \& Steele, C. (2007). Speech motor control in fluent and dysfluent speech production of an individual with apraxia of speech and Broca's aphasia. Clinical Linguistics \& Phonetics, 21, 159-188.

Walden, T., Frankel, C., Buhr, A., Johnson, K., Conture, E. \& Karrass, J. (2012). Dual diathesisstressor model of emotional and linguistic contributions to developmental stuttering. Journal of Abnormal Child Psychology, 40, 633-644.

Watanabe, M., Hirose, K., Den, Y. \& Minematsu, N. (2008). Filled pauses as cues to the complexity of upcoming phrases of native and non-native listeners. Speech Communication, 50, 81-94.

Yaruss, J. S. (1997). Clinical measurement of stuttering behaviors. Contemporary Issues in Communication Science and Disorders, 24, 33-44.

Yaruss, J. S. (2004). Speech disfluency and stuttering in children. Teoksessa R. D. Kent (toim.), (s. 180-183), The MIT encyclopedia of communication disorders. Cambridge, MA: Massachusetts Institute of Technology. 


\section{TYPICAL FLUENCY IN FINNISH ADULTS}

Nelly Penttilä, Faculty of Social Sciences, University of Tampere Anna-Maija Korpijaakko-Huuhka, Faculty of Social Sciences, University of Tampere Raymond D. Kent, Waisman Center, University of Wisconsin-Madison

The aim of this study was to investigate speech disfluencies in non-disordered Finnish adult speakers to gain normative data of typical fluency in Finnish. Narrative speech samples from 70 healthy adults were analyzed for disfluency types and their frequencies, as well as for relations between various disfluencies. The most common disfluency type was hesitation, and the mean disfluency frequency was $2,34 \%$ (range $=0,0-7,8 \%$ ). Revisions, word repetitions and hesitations were statistically significant components of disfluency. As the disfluency frequency increased, the most common disfluency type changed. In factor analysis, four factors were found: disfluencies related to 1) language formulation (interruptions and revisions), 2) planning the message (hesitation and interjections), 3) maintaining fluency (word-and phrase repetitions) and 4) articulation (sound-and syllable repetitions). Of these factors, disfluencies related to language formulation and fluency maintenance contributed statistically significantly to disfluency frequency. The results support the view that fluency manifests as a continuum with wide variation of different disfluencies. These results serve as a normative reference for future studies and help clinicians in assessing fluency disorders.

Keywords: adults, disfluencies, fluency, normal variation, typical speech 